\title{
ECONOMICA
}

Jurnal Program Studi Pendidikan Ekonomi

STKIP PGRI Sumatera Barat Vol.9 No.1 (151 - 160)

\section{FACTORS AFFECTING CORPORATE SOCIAL RESPONSIBILITY DISCLOSURE: A PANEL DATA STUDY}

\author{
By \\ Irdha Yusra'), Rizka Hadya ${ }^{2)}$ \\ 1) Students in the Doctoral Program in Management Science, Andalas University \\ Email: irdhayusra@gmail.com \\ 2) Faculty of Economic, Ekasakti University. Indonesia \\ 2) Email: rizkahadya@gmail.com
}

Submitted: 2021.01.23 Reviewed: 2021.04.28 Accepted:2021.04.28

https://doi.org/10.22202/economica.2021.v9.i2.4626

\begin{abstract}
This paper investigates corporate social responsibility (CSR) disclosure in Indonesia. Specifically, we examine whether profitability and leverage affect the CSR disclosure of companies listed on the Indonesia Stock Exchange. The analytical method used is panel data regression analysis. By examining the 129 companies listed in Indonesia Stock Exchange, we find that there is both-positive impact of profitability and negative impact of leverage on CSR disclosure significantly. The findings are consistent across one measures of a firm's profitability (ROA, ROE, and $R O I)$ and one proxies of leverage (DAR and DER). This study provides quantitative evidence on the positive effect of profitability on CSR disclosure. In addition, this study also provides empirical evidence about the effect of leverage on CSR disclosure in Indonesia We have successfully contributed to the determinants of CSR disclosure.
\end{abstract}

Jel Classification:

I21; I28; J24

Keywords: Corporate Social Responsibility, Profitability, Leverage, Panel Data 


\section{INTRODUCTION}

Previous research has not produced a consistent understanding of the relationship between corporate financial performance and CSR disclosure. Theoretically, information asymmetry plays an important role in answering this understanding (C. Chen \& Liu, 2013; Ripamonti, 2020). The condition of information asymmetry is strongly influenced by the availability of relevant information on the market, either financial or non-financial. Financial information has been studied in previous literature (Maqbool \& Zameer, 2018; Rhou et al., 2016; Kim et al., 2012; Gs et al., 2020). However, non-financial information should also be considered by companies. This research usually assumes that nonfinancial information is relevant to value and acts as additional information for stakeholders and market players. Hitherto, studies on non-financial information, in particular CSR disclosure studies have reported that companies engaged in environmentally and socially sensitive industries pay more attention to sustainability issues, while companies engaged in industries that are not sensitive to the environment do not carry out CSR activities (Dhaliwal et al., 2011, 2012). Information is a consideration because it is voluntary. There is a little research about how companies engaged in industries that are not sensitive to the environment to CSR practices The empirical research in this area is due to the nature of voluntary disclosure.

Company's reason for voluntarily disclosing CSR activities is to gain a competitive advantage and meet community expectations. Apart from that, it also aims to attract investors. This activity is a form of the company's contribution in reducing the negative impacts arising from stakeholders who have interests. Ideally, the company's existence should be beneficial to the surrounding community, so that it is hoped that the implementation of CSR in addition to empowering the local community is also an effort to make the company's operations run smoothly without interruption. In the investment decisionmaking process, investors include variables related to CSR, especially in social and environmental sustainability issues (Astuti \& Nugrahanti, 2015). CSR activities certainly have different impacts even though they are in the same type of business. This is due to the different characteristics of the company. As for the problems that occur in CSR, there are still many companies that have not carried out CSR activities due to unavailability of funds for carrying out these activities.

We investigate the fundamental factors that can influence CSR disclosure. Our hypothesis are based on studies that have established a relationship between profitability, leverage, and CSR disclosure in Indonesia. More precisely, we examine the effect of profitability on CSR disclosure, and the effect of leverage on CSR disclosure. All dominant indicators used by previous studies were included in the measurement of each variable where profitability is proxied by ROA, ROI, ROI, GPM, and NPM. Meanwhile, leverage is measured using the DAR and DER indicators.

This paper has three (3) contributions. First, this paper examines the effect of profitability on CSR disclosure. Second, it examines the effect of leverage on CSR disclosure. Third, this paper describes the effect of profitability and leverage on CSR disclosure in all industrial sectors listed on the Indonesia Stock Exchange. In a nutshell, this study of CSR disclosure is not grouped based on the type of industry such as financial and / or nonfinancial. Instead, the data is set and tested thoroughly for all companies registered in Indonesia.

From a theoretical perspective, almost all previous empirical studies have examined the relationship between corporate financial performance and CSR disclosure (Devi et al., 2011). On one side, CSR disclosure is seen as a method of responding to changes in public perceptions that are relevant to the company. On the 
other hand, legitimacy theory argues that companies use sustainability disclosure to increase public perceptions of their sustainability performance (Hummel \& Schlick, 2016).

In many cases, the theory of legitimacy includes the contract between the company and the community. The company's survival will be threatened if the company violates the contract it has made (Robert E, 2005). This legitimacy can be seen as something that the company wants the community to do and vice versa. This social contract contains rights and obligations, which of course will change according to community conditions. This social contract will become the company's reference in adapting its objectives to the objectives of society, whose implementation will be realized in the form of corporate social responsibility (Ali \& Rizwan, 2013; Chauvey et al., 2015; Michelon \& Parbonetti, 2012).

Legitimacy theory has a strong correlation between the company and the community (Juhmani, 2014). The existence of a company is certainly supported by several things including the community and the environment around it. If the company runs its business in accordance with the values set by the community, it will not be surprising that the company will immediately been legitimate by the community. Furthermore, legitimacy theory suggests that companies with poor environmental performance are expected to provide more broad setting or positive environmental disclosures in their financial reports (Cho \& Patten, 2007).

\section{Profitability as a determinant of CSR Disclosure}

Several previous studies have discussed some factors that influence CSR disclosure (Ali \& Rizwan, 2013; Cui et al., 2018; Dhaliwal et al., 2012). A high level of profitability reflects that the company is able to increase its social responsibility as well as to carry out reporting responsibilities on financial statements more broadly. Profitability shows the success of a company in generating company profits. Companies that have some good financial conditions will also get stronger pressure from the corporate environment to broadly disclose CSR.

When companies get high profits, the level of disclosure of Corporate Social Responsibility will also be high (Nugroho \& Yulianto, 2015). Conversely, when the company gets low profits, the level of CSR disclosure will also be low. Meanwhile, profitability has a positive effect on CSR disclosure (Yanti \& Budiasih, 2016). This is also supported by the research which proves the same result that profitability has a positive effect on disclosure of Corporate Social Responsibility (Pradnyani \& Sisdyani, 2015). However, this is contradictory to the research of Indraswari and Mimba (2017) by establishing food and beverage companies listed on the Indonesia Stock Exchange as the object of their research. Their research findings prove that profitability has no effect on the level of corporate social responsibility disclosure.

Based on the explanation above, the first hypothesis is built as follows:

\section{H1: Profitability has a positive and significant effect on CSR disclosure Leverage as a determinant of CSR Disclosure}

Another factor that also affects CSR is Leverage (Kim et al., 2012; Maqbool \& Zameer, 2018; Ruroh \& Latifah, 2018a). According to Sembiring 2005, companies that have a high degree of leverage mean that they are very dependent on external loans to finance their assets. Meanwhile, companies that have a low level of leverage mean that they are financing their assets with their own capital.

Level of leverage is very important for the company. Because, this ratio can determine whether CSR activities are carried out or not. Companies that have a high level of leverage will have a low level of CSR disclosure. Conversely, when the company has a low level of leverage, the implementation or disclosure of CSR will 
be high. Furthermore, (Ruroh \& Latifah, $2018 b$ ) revealed that companies with a high level of leverage will reduce social responsibility disclosures so that they are not closely monitored or avoid special supervision from debt holders. However, Sunaryo and Mahfud (2016) stated that leverage does not have a positive effect on Corporate Social Responsibility .

Based on the description above, the second hypothesis is formulated as follows:

H2: Leverage has a negative and significant effect on CSR disclosure.

\section{METHODS}

\section{Data and sample}

This research uses purposive sampling method in selecting the obtained population. Population were 600 companies listed on the Indonesia Stock Exchange at the end of the 2018 period. To obtain the final sample, this study filtered the data using several considerations. Due to this study was set using panel data, companies that were not listed consecutively during the 2014-2018 period were not included in the sample. There were 134 companies that were not registered during that period. As a second consideration, each company must have financial statements during the observation period. There were 175 companies that did not have complete financial reports. Then, the existing companies are selected by considering the completeness of the data according to the research variables. Thus, there were 114 companies that did not have the required data. As a final consideration, the research eliminates companies that have outliers, namely 48 companies. So that the data filtering process obtained 129 companies as samples.

\section{Variables and measurement}

We describe some of the explanatory variables and measurement indicators for each variable in this session. In this study, the variable corporate social responsibility (CSR) is used as the dependent variable. Measurement indicators use a comparison between the number of CSR disclosures with the maximum score (Hummel \& Schlick, 2016), (Rusmanto \& Williams, 2015), (Purba \& Yadnya, 2015). Profitability and leverage as independent variables. Profitability is measured using several indicators, namely ROA, ROE, ROI, GPM, and NPM (Y. Chen et al., 2018), (Fahmi, 2016). Meanwhile, leverage is measured using only two indicators, namely DER and DAR (Fahmi, 2016), (Sheikh, 2018).

The main model used to estimate the causal relationship between profitability and leverage with corporate social responsibility (CSR), we built a panel data regression model (Karabiyik et al., 2016; D. H. Chen et al., 2013; Yusra, Hadya, \& Fatmasari, 2019; Yusra, Hadya, Begawati, et al., 2019). The models used are as follows:

$C S R_{i t}=\alpha+\beta_{1} R O A_{i t}+\beta_{2} D A R_{i t}+e \ldots .$.

(I)

$C S R_{i t}=\alpha+\beta_{1} R O A_{i t}+\beta_{2} D E R_{i t}+e \ldots .$.

(II)

$\operatorname{CSR}_{i t}=\alpha+\beta_{1} R O E_{i t}+\beta_{2} D A R_{i t}+$

$e$......(III)

$C S R_{i t}=\alpha+\beta_{1} R O E_{i t}+\beta_{2} D E R_{i t}+e \ldots .$.

(IV)

$C S R_{i t}=\alpha+\beta_{1} R O I_{i t}+\beta_{2} D A R_{i t}+e \ldots . .(\mathrm{V})$

$C S R_{i t}=\alpha+\beta_{1} R O I_{i t}+\beta_{2} D E R_{i t}+e \ldots .$.

(VI)

$C S R_{i t}=\alpha+\beta_{1} G P M_{i t}+\beta_{2} D A R_{i t}+e \ldots$.

(VII)

$C S R_{i t}=\alpha+\beta_{1} G P M_{i t}+\beta_{2} D E R_{i t}+e \ldots$

(VIII)

$C S R_{i t}=\alpha+\beta_{1} N P M_{i t}+\beta_{2} D A R_{i t}+e \ldots$.

(IX)

$C S R_{i t}=\alpha+\beta_{1} N P M_{i t}+\beta_{2} D E R_{i t}+e \ldots$.

$(\mathrm{X})$

CSR it is a Corporate Social Responsibility at time $t ; \alpha$ is a constant; $\beta$ is the regression coefficient; ROA it is the Return on Assets at time t; ROE it is the Return on Equity at time t; ROI it is the Return on Investment at time t; GPM it is the Gross Profit Margin at time t; NPM it is the Net Profit Margin at time t; DAR it is the Debt to Asset Ratio at time t; DER it is the Debt to Equity Ratio at time t; e is the error term. 
RESULTS AND DISCUSSION

Table 1 presents descriptive statistics for all measures used in our panel model analysis of all 129 firms or 645 observations.

Table 1. Descriptive Statistics

\begin{tabular}{ccccc}
\hline Variables & Min & Max & Mean & S.D \\
\hline CSR & 0.02 & $\begin{array}{c}\text { Dependent variable } \\
0.09\end{array}$ & 0.05 & 0.01 \\
& & Independent variable & & \\
Profitability & -43.63 & 46.66 & 4.58 & 7.89 \\
ROA & -135.22 & 135.85 & 8.00 & 18.81 \\
ROE & -98.86 & 93.27 & 10.78 & 20.48 \\
ROI & -14.17 & 94.93 & 27.42 & 19.40 \\
GPM & -284.02 & 1509.28 & 9.97 & 63.50 \\
NPM & 0.07 & 6.10 & 0.53 & 0.46 \\
Leverage & 0.08 & 624.96 & 2.27 & 24.60 \\
DAR & $\quad$ Number of observations $=645$ \\
DER & \multicolumn{2}{c}{} & \\
\hline
\end{tabular}

The table shows the min, max, mean, and, S.D for each study variable.

Data source: financial reports obtained from the Indonesia Stock Exchange website

CSR as the dependent variable has a mean value of 0.05 , which reveals that there is very few companies disclose CSR on average. The average ROA of 4.58 indicates that 458 percent of profit is generated from total assets. Meanwhile, an average ROE of 8.00 indicates that on average all companies are able to use $800 \%$ of shareholders' equity to increase profits. The average ROI is 10.78 , which means that on average all companies are able to use $1078 \%$ of their total assets as a whole to increase profits. The average GPM is 27.42 , which means that on average all companies use their total revenue of $2742 \%$ to assess gross profit. The average NPM of 9.97 shows that on average all companies use total sales of $977 \%$ to obtain net income. With respect to DAR and DER as measures of firm leverage, the reported value for DAR is 0.53 , and for DER is 2.27 which reveals that the average liabilities of the total asset value for the sample of firms Hypothesis testing

We use panel data regression to estimate the corporate social responsibility (CSR) model for all companies from 2014 to 2018. Tables 2 and 3 show the results of the analysis of the panel data model for Equation (1) to (10).

Table 2. Panel Data Analysis of Equation (1) to (5)

\begin{tabular}{cccccc}
\hline Variable & Eq. (1) & Eq. (2) & Eq. (3) & Eq. (4) & Eq. (5) \\
\hline ROA & 1.545906 & $1.808368^{*}$ & & & \\
ROE & & & $1.955369^{*}$ & $2.059323^{* *}$ & $1.658078^{*}$ \\
ROI & & & & $-2.099408^{* *}$ \\
DAR & $-1.977539 * *$ & & $-2.090399^{* *}$ & & -0.148030 \\
DER & & -0.155039 & & \\
\hline
\end{tabular}

Note: Dependent variable $=$ CSR; t-statistics in brackets, $*$, **, and $* * *$ denote the statistical significance at the 10, 5 and 1 per cent (two tailed) test levels, respectively 
Table 3. Panel Data Analysis of Equation (6) to (10)

\begin{tabular}{cccccc}
\hline Variable & Eq. (6) & Eq. (7) & Eq. (8) & Eq. (9) & Eq. (10) \\
\hline ROI & $1.770433^{*}$ & & & & \\
GPM & & 0.442060 & 0.514207 & & \\
NPM & & & 0.168473 & 0.218448 \\
DAR & & $-2.179093^{* *}$ & & $-2.189340^{* *}$ & \\
DER & -0.115896 & & -0.147575 & & -0.147492 \\
\hline
\end{tabular}

Note: Dependent variable $=$ CSR; t-statistics in brackets, $*$, **, and *** denote the statistical significance at the 10,5 and 1 per cent (two tailed) test levels, respectively

Statistically, Tables 2 and 3 prove that ROA, ROE, and ROI have a positive and significant effect on CSR. Thus, the first hypothesis which states that profitability has an effect on CSR is accepted. The regression model estimate between leverage and CSR also indicates a negative and significant result. In absolute terms DAR and DER have a t-statistic value that is greater than the t-table. These results conclude that the second hypothesis which states that leverage has a negative and significant effect on CSR is accepted.

\section{Effect of Profitability on Corporate Social Responsibility}

Based on the tests that have been carried out, it can be concluded that the first hypothesis, namely profitability, has a positive and significant effect on CSR is acceptable, because the three indicators of measuring the profitability variable show significant results. This means that profitability affects companies in carrying out CSR activities. These results indicate that the higher the level of profitability of a company, the managers are more motivated to provide more detailed information, including the freedom to show and account for all of its social programs.

This finding is consistent with legitimacy theory (Chauvey et al., 2015; Robert E, 2005). This theory is a strategy carried out by the company in terms of developing the company for the future. Therefore, a high level of profitability will make managers more motivated to disclose social information, in addition to convincing investors with a high level of profitability, the company will also build and gain a good name in the eyes of investors and the public.

Relevant to previous research conducted by (Munsaidah et al., 2016) which states that the greater the profit, the wider the company will be in terms of disclosing its social information, profitability affects CSR activities. (Putri, 2017) in her research stated that companies with high profits certainly have a lot of funds so that they can carry out CSR activities more widely. The higher the profit a company gets, the more motivated managers will be to disclose information, including in terms of being accountable for all their social activities as well as convincing investors with high levels of profitability (Ruroh \& Latifah, 2018a).

\section{The Influence of Leverage on Corporate Social Responsibility}

Based on the tests that have been done, it can be concluded that the second hypothesis, namely leverage, has a negative and significant effect on CSR. This means that leverage is one of the determining factors for the high or low level of CSR activities. This negative relationship implies that management with a high degree of leverage tends to reduce social responsibility disclosures so that they do not become the spotlight of debtholders. In 
addition, the higher the level of leverage, the more likely the company will violate the credit agreement, so that the company will try to report higher current profits than future profits.

Management's ability to manage fundamental financial performance in the form of leverage is one of the keys to increasing CSR (Sartono, 2013). Leverage is very important for stakeholders to measure the risk in investing, as well as being a driver for improving financial performance or other company activities. High-risk companies usually try to convince creditors with more detailed information disclosure (Ruroh \& Latifah, 2018b). High leverage will result in supervision carried out by the debtholder. Therefore, management with a high level of leverage will divert the attention of debt holders by minimizing CSR disclosures made by the company. This research is in accordance with research conducted by (Ruroh and Latifah 2018b) which proves that leverage has an effect on CSR (Ruroh \& Latifah, 2018a), (Sheikh, 2018).

\section{CONCLUSION}

This study was conducted by using profitability and leverage as the main factors in determining CSR disclosure. By utilizing the financial report data of companies listed in the period 2014 to 2018 on the Indonesia Stock Exchange, this study produces two conclusions, namely first, profitability has a positive and significant effect on CSR disclosure. Second, leverage has a negative and significant effect on CSR disclosure. In other words, profitability and leverage are determinants of CSR disclosure. This finding supports the legitimacy theory.

This study provides methodological implications using a panel data approach. Panel data models allow in the most important and fundamental process of estimating consistent results from other parameters. The consistency of the findings may be carried out by subsequent research, namely including control variables such as company size and company age. Critically, the results of this study also paved the way for other researchers to take other approaches, for example dividing companies into similar sectors / industries, and / or conducting robutness tests.

\section{REFERENCES}

Ali, W., \& Rizwan, and M. (2013). Factor Influencing Corporate Social And Environmental Disclosure (CSED) Practice In The Developing Countries: An Institutional Theoretical Perspectives. International Journal of Asian Social Science, 3(3), 590-609.

Astuti, C. W., \& Nugrahanti, Y. W. (2015). Pengaruh Pengungkapan Corporate Social Responsibility Terhadap Reaksi Pasar. Dinamika Akuntansi, Keuangan Dan Perbankan, 4(2), 90105.

Chauvey, J. N., Giordano-Spring, S., Cho, C. H., \& Patten, D. M. (2015). The Normativity and Legitimacy of CSR Disclosure: Evidence from France. Journal of Business Ethics, 130(4), 789-803.

https://doi.org/10.1007/s10551-0142114-y

Chen, C., \& Liu, V. W. (2013). Corporate Governance Under Asymmetric Information: Theory and Evidence. Economic Modelling, 33, 280-291. https://doi.org/10.1016/j.econmod.20 13.04.010

Chen, D. H., Chen, C. Da, Chen, J., \& Huang, Y. F. (2013). Panel data analyses of the pecking order theory and the market timing theory of capital structure in Taiwan. International Review of Economics and Finance, 27, $1-13$. https://doi.org/10.1016/j.iref.2012.09. 011

Chen, Y., Hung, M., \& Wang, Y. (2018). The Effect of Mandatory CSR Disclosure on Firm Profitability and 
Social Externalities: Evidence from China. Journal of Accounting and Economics, 65(1), 169-190. https://doi.org/10.1016/j.jacceco.2017 .11 .009

Cho, C. H., \& Patten, D. M. (2007). The role of environmental disclosures as tools of legitimacy: A research note. Accounting, Organizations and Society, 32(7-8), 639-647. https://doi.org/10.1016/j.aos.2006.09. 009

Cui, J., Jo, H., \& Na, H. (2018). Does Corporate Social Responsibility Affect Information Asymmetry? Journal of Business Ethics, 148(3), 549-572.

https://doi.org/10.1007/s10551-0153003-8

Dan, P. A. (2010). Pengaruh Kinerja Keuangan Terhdap Nilai Perusahaan Dengan Pengungkapan Corporate Social Responsibility Dan Good Governance Sebagai Variabel Pemodernisasi. Universitas Stuttgart, $1-63$.

Devi, J., Oogarah-hanuman, V., \& Soobaroyen, T. (2011). Changes in social and environmental reporting practices in an emerging economy ( 2004-2007): Exploring the relevance of stakeholder and legitimacy theories. Accounting Forum, 35(3), 158-175. https://doi.org/10.1016/j.accfor.2011. 06.005

Dhaliwal, D. S., Li, O. Z., Tsang, A., \& Yang, Y. G. (2011). Voluntary nonfinancial disclosure and the cost of equity capital: The initiation of corporate social responsibility reporting. Accounting Review, 86(1), 59-100.

https://doi.org/10.2308/accr.0000000 5

Dhaliwal, D. S., Radhakrishnan, S., Tsang, A., \& Yang, Y. G. (2012). Nonfinancial disclosure and analyst forecast accuracy: International evidence on corporate social responsibility disclosure. Accounting Review, 87(3), 723-759. https://doi.org/10.2308/accr-10218

Fahmi, I. (2016). Pengantar Manajemen Keuangan (M. B. . Muslim A. Djalil, S.E., Ak. (ed.)). ALFABETA, CV.

Gs, A. D., Rahmawati, A., Susena, K. C., Dwi, R., Maulana, Y. S., Yusra, I., \& Firmansyah, M. R. (2020). Impacts of Regional Financial Performance and Private Investment on Public Welfare In East Java. International Journal of Psychosocial Rehabilitation, 24(08), 12450-12457.

Hummel, K., \& Schlick, C. (2016). The Relationship between Sustainability Performance and Sustainability Disclosure - Reconciling Voluntary Disclosure Theory and Legitimacy Theory. Journal of Accounting and Public Policy, 41, 1-22. https://doi.org/10.1016/j.jaccpubpol.2 016.06.001

Juhmani, O. (2014). Determinants of Corporate Social and Environmental Disclosure on Websites: the Case of Bahrain. Universal Journal of Accounting And Finance, 2(4), 77-87. https://doi.org/10.13189/ujaf.2014.02 0402

Karabiyik, H., Westerlund, J., \& Narayan, P. (2016). On the estimation and testing of predictive panel regressions. Journal of International Financial Markets, Institutions and Money, 45, 115-125.

https://doi.org/10.1016/j.intfin.2016.0 7.003

Kim, Y., Park, M. S., \& Wier, B. (2012). Is earnings quality associated with corporate social responsibility? Accounting Review, 87(3), 761-796. https://doi.org/10.2308/accr-10209

Maqbool, S., \& Zameer, M. N. (2018). Corporate social responsibility and 
financial performance: An empirical analysis of Indian banks. Future Business Journal, 4(1), 84-93. https://doi.org/10.1016/j.fbj.2017.12. 002

Michelon, G., \& Parbonetti, A. (2012). The effect of corporate governance on sustainability disclosure. Journal of Management and Governance, 16(3), 477-509.

https://doi.org/10.1007/s10997-0109160-3

Munsaidah, S., Andini, R., \& Supriyanto, A. (2016). Analisis Pengaruh Firm Size, Age, Profitabilitas, Leverage, dan Growth Perusahaan terhadap Corporate Social Responsibility (CSR) pada Perusahaan Property dan Real Estate yang Terdaftar di Bursa Efek Indonesia Pada Tahun 20102014. Journal Of Accounting, 2(2).

Nugroho, M. N., \& Yulianto, A. (2015). Pengaruh Profitabilitas dan Mekanisme Corporate Governance Terhadap Pengungkapan CSR Perusahaan yag terdaftar di JII 20112013. Accounting Analysis Journal, $4(1), 1-12$.

Pradnyani, I. gusti A. A., \& Sisdyani, E. A. (2015). Pengaruh Ukuran Perusahaan, Profitabilitas, dan Ukuran Dewan Komisaris pada Pengungkapan Tanggung Jawab Sosial Perusahaan. E-Jurnal Akuntansi Universitas Udayana, 11(2), 384-397.

Purba, I. B. G. I. W., \& Yadnya, P. (2015). Pengaruh Ukuran Perusahaan dan Leverage terhadap Profitabilitas dan Pengungkapan Corporate Social Responsibility. E-Jurnal Manajemen Unud, 4(8), 2428-2443.

Putri, R. K. (2017). Pengaruh Ukuran Perusahaan, Profitabilitas, Leverage, Likuiditas, dan Basis Kepemilikan terhadap Corporate Social Responsibility pada Perusahaan Pertambangan yang Terdaftar di Bursa
Efek Indonesia (BEI) Periode Tahun 2012 - 2014. JOM Fekon, 4(1), 558571.

Rhou, Y., Singal, M., \& Koh, Y. (2016). CSR and Financial Performance: The Role of CSR Awareness in the Restaurant Industry. International Journal of Hospitality Management, 57 , 30-39. https://doi.org/10.1016/j.ijhm.2016.0 5.007

Ripamonti, A. (2020). Financial Institutions, Asymmetric Information and Capital Structure Adjustments. Quarterly Review of Economics and Finance, 1-9. https://doi.org/10.1016/j.qref.2020.01 .010

Robert E, J. (2005). Disclosures in Corporate Environmental Reports: A Test of Legitimacy Theory. Kent Academic Repository, 91, 1-34.

Robiah, A. M., \& Erawati, T. (2017). Pengaruh Leverage, Size, dan Kepemilikan Manajemen terhaap Corporate Social Responsibility Disclosure. AkuntansI Dewantara, 1(1), 39-48.

Ruroh, I. N., \& Latifah, S. W. (2018a). Pengaruh Profitabilitas, Leverage, Ukuran Perusahaan dan Risk Minimization terhadap Pengungkapan Corporate Social Responsibility (CSR). Jurnal Akademi Akuntansi, 1(1), 42-53.

Ruroh, I. N., \& Latifah, S. W. (2018b). Pengaruh Profitabilitas, Leverage, Ukuran Perusahaan dan Risk Minimization terhadap Pengungkapan Corporate Social Responsibility (CSR). Jurnal Akademi Akuntansi, 1(11), 42-53.

Rusmanto, T., \& Williams, C. (2015). Compliance Evaluation on CSR Activities Disclosure in Indonesian Publicly Listed Companies. Procedia - Social and Behavioral Sciences, 172, 
$150-156$.

https://doi.org/10.1016/j.sbspro.2015. 01.348

Sartono, A. (2013). Manajemen Keuangan Teori dan Aplikasi (5th edition). BFFE-UGM.

Sembiring, E. R. (2005). Karakteristik Perusahaan dan Pengungkapan Tanggung Jawab Sosial: Study Empiris pada Perusahaan yang tercatat di Bursa Efek Jakarta. SNA VIII, 379395.

Sheikh, S. (2018). Corporate Social Responsibility and Firm Leverage: The Impact of Market Competition. Research in International Business and

Finance. https://doi.org/10.1016/j.ribaf.2018.1 1.002

Yanti, N. K. A. G., \& Budiasih, I. G. A. N. (2016). Pengaruh Profitabilitas, leverage dan ukuran perusahaan pada pengungkapan Corporate Social Responsibilty. E-Jurnal Akuntansi Universitas Udayana, 17(3), 17521779.

Yusra, I., Hadya, R., Begawati, N., \& Istiqomah, L. (2019). Panel data model estimation: the effect of managerial ownership, capital structure, and company size on corporate value Panel data model estimation: the effect of managerial ownership, capital structure, and company size on corporate value. Journal of Physics: Conference Series, 1175, 1-6. https://doi.org/10.1088/17426596/1175/1/012285

Yusra, I., Hadya, R., \& Fatmasari, R. (2019). The Effect of Retained Earnings on Dividend Policy from the Perspective of Life Cycle. Advances in Social Science, Education and Humanities Research, 203(Iclick 2018), 216-220. 